\title{
9. RADIOLARIANS FROM SEDIMENTS OF THE PHILIPPINE SEA, DEEP SEA DRILLING PROJECT LEG 58
}

\author{
Jon Sloan, Department of Geology, University of California-Davis
}

\section{INTRODUCTION}

Radiolarians were observed at all five sites drilled during DSDP Leg 58 . Three sites $(442,443,444)$ are south of Japan in the Shikoku Basin. The remaining two sites $(445,446)$ are east of Okinawa, in the Daito Ridge and Basin areas.

The observations made on radiolarians during Leg 58 are understood best by considering these two areas separately. The basement ages, preservation, diagenesis, and paleoecology are similar within each area, but different between the two areas.

The radiolarian zones of Riedel and Sanfilippo (1978) were used to determine the sediment age (Figure 1). Because of the mixed nature of the fauna, there was an opportunity to test the tropical zonation in middlelatitude sediments.

A middle- to high-latitude biostratigraphy for the Pliocene and Pleistocene has been formulated (Hays, 1970; Kling, 1973; Foreman, 1975), but there is no Miocene radiolarian zonation for these latitudes. The tropical elements of the present fauna are sufficient to use the low-latitude zonation, although there is a loss of resolution in the Pleistocene. Because of poor preservation, zone boundaries are indistinct in much of the cored sediment.

Determination of abundance in any sample is always subjective and varies among investigators. This work was in its final stages at the publication of Westberg and Riedel (1978), and the guidelines outlined therein are not closely followed.

The abundances recorded in Tables 1 through 5 are based on strewn slides which were searched entirely if an individual of a species was found, or for 8 to 10 minutes if the species was not found.

\section{THE SHIKOKU BASIN: SITES 442, 443, AND 444}

Sediments from Sites 442,443 , and 444 are characterized by an abundant and well-preserved Pleistocene fauna, a nearly barren Pliocene section, and a middle-to late-Miocene fauna with varied preservation which is never as good as that of the younger material. A high amount of volcanic ash is found at all sites throughout the Neogene and Quaternary. The oldest sediment in the basin which can be dated using radiolarians is middle Miocene.

The ecology and paleoecology of plankton in the Shikoku Basin probably is controlled mainly by the Kuroshio Current, which is the dominant oceanographic feature of the region. The path of this current determines the nature of the plankton, which is, in turn, reflected in the sediments. South of Japan, the Kuroshio exhibits a periodic meander which shifts offshore and remains stable for several years (Taft, 1972). The Kuroshio brings with it a tropical fauna, and when it is not present cold waters from the north and east dominate. These fluctuations result in mixed tropical and middle- to high-latitude faunas. A tracing of the path of the Kuroshio was attempted, but wide sampling intervals and poor preservation allowed only the most general conclusions.

\section{Site $\mathbf{4 4 2}$}

Well-preserved, abundant radiolarians are in the Quaternary section at this site (Cores 442-1 to 442A-4). These belong to the Lamprocyrtis haysi Zone, which here extends from the sea floor to 38 meters.

From about 38 meters to 218 meters (Cores $442 \mathrm{~A}-5$ to 442A-23), no radiolarians are found, with the exception of Core $442 \mathrm{~A}-19$ at 180.5 meters, where a few radiolarians were recovered.

Below this barren region, to the bottom of the hole, Miocene radiolarians are found. Core 442A-24 (218-228 $\mathrm{m})$ is lower upper Miocene (Ommatartus antepenultimus Zone). Core 442A-25 contains radiolarians of the Cannartus petterssoni Zone (middle Miocene). From 237.5 to 247 meters, Core $442 \mathrm{~A}-26$ is lower middle Miocene in the Dorcadospyris alata Zone, as is Core $442 \mathrm{~A}-27$, which is the oldest core datable by radiolarians.

\section{Site 443}

Abundant, well-preserved radiolarians are seen in only the first three cores at this site, from the sediment surface to 26 meters. As at Site 442 , Pliocene radiolarians are very rare and Cores $443-4$ through $443-21$ are barren. In Cores 443-22 through 443-35, only occasional intervals have enough radiolarians for stratigraphic use.

The radiolarians of Cores 443-1 through 443-3 belong to the Quaternary Lamprocyrtis haysi Zone. Because of poor preservation, older sediments are less confidently dated.

Core 443-27 (244.5-254 m) contains the best-preserved Miocene radiolarians at this site. representing the late-Miocene Stichocorys peregrina Zone. Radiolarians found in Core 443-31 are thought to represent the upper middle Miocene (Dorcadospyris alata Zone). The remainder of the cores at Site 443 are mostly barren, although one specimen of Eucyrtidium yatuoense was recovered from Core 443-48. This species is found in the lower Oligocene to lower middle Miocene at Site 296 of DSDP Leg 31 (Ling, 1975). 


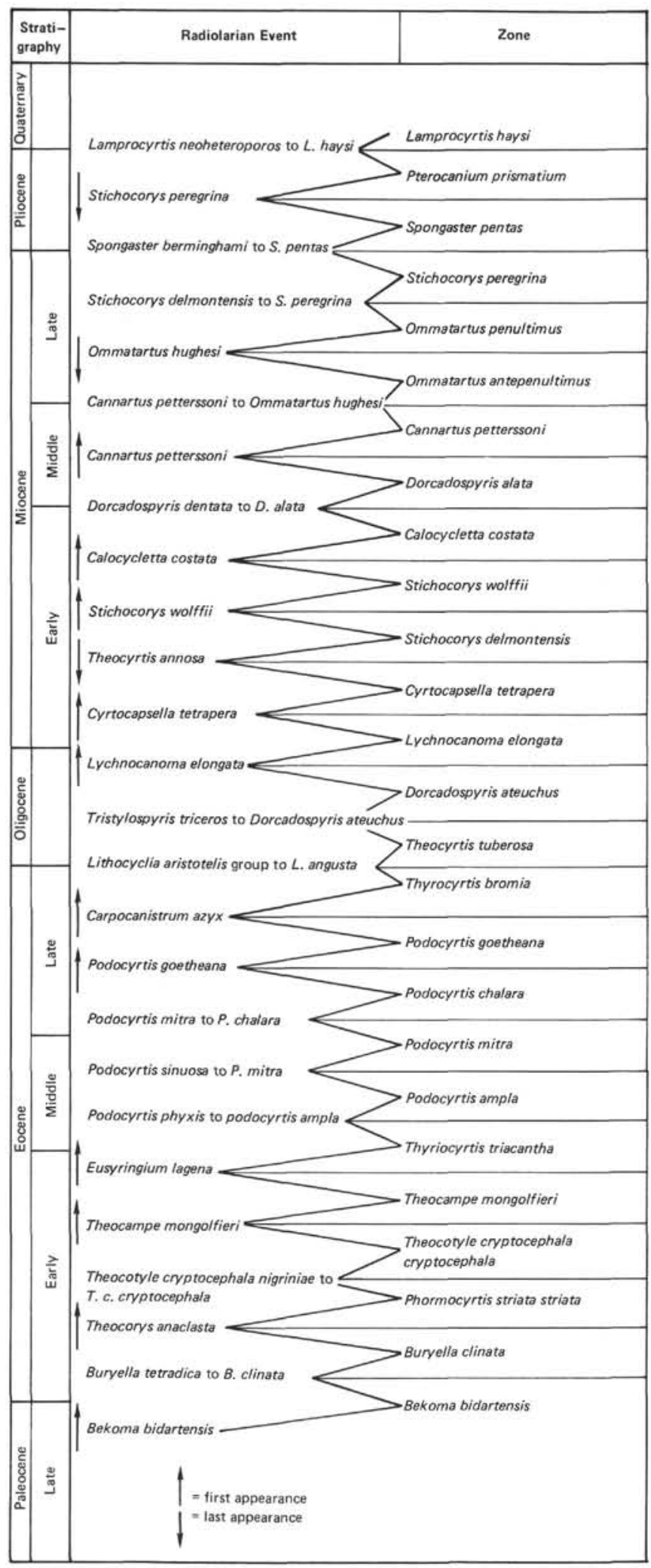

Figure 1. A tropical Cenozoic radiolarian zonation. The radiolarian zones are listed in stratigraphic order on the right, with their defining events on the left. Arrows indicate first and last occurrences. After Riedel and Sanfilippo (1978).

\section{Site 444}

Two holes were drilled at this site. Hole 444 yielded Quaternary radiolarians in Cores 444-1 through 444-5 (0-44 m). Cores 444-6 through 444-10 do not contain radiolarians. Hole 444A yielded Miocene radiolarians; as at Sites 442 and 443, the Pliocene is barren of radiolarians, but can be dated using nannofossils (Okada, this volume). Cores 44A-1 through 444A-5 (82-129.5 m) contain late-Miocene radiolarians of the Stichocorys peregrina Zone. The zonel guide Cannartus petterssoni was not seen, so zonel assignments of Cores 444A-8 through $444 \mathrm{~A}-12$ are not exact. These cores represent either the Cannartus petterssoni Zone or Ommatartus antepenultimus Zones (upper middle to lower upper Miocene). The remaining cores at Site 444 containing radiolarians 444-13 through 444a-23) are middle Miocene, but in the absence of Dorcadospyris, a greater age cannot be excluded for the bottom of the hole.

\section{DAITO RIDGE AND BASIN AREA: SITES 445 AND 446}

Sites 445 and 446 are characterized by very thick sediments with thin or missing Quaternary, thick Eocene, and poor radiolarian preservation throughout.

Site 445 yielded radiolarians from only a few of the 94 cores. Cores $445-1$ and $445-2$ contain Quaternary radiolarians, but Cores 445-3 through 445-30 are barren. Although Cores $445-31$ through $445-58$ are mostly barren, a few contain poorly preserved Miocene radiolarians. Cores 445-63 through 445-66 contain Oligocene to middle-Eocene radiolarians. No radiolarians were seen below Core 66,626 to 892 meters.

Only two cores at Site $\mathbf{4 4 6}$ yielded radiolarians. The radiolarians of Core 446-9 $(68-77.5 \mathrm{~m})$ are Miocene (Calocycletta costata Zone), and those of Core 446-17 (144-153.5 m) are Eocene (Podocyrtis chalara Zone). The lack of radiolarians in the bottom of Holes 445 and 446 is most likely due to mobilization of silica and formation of chert which is seen in these Eocene sediments.

\section{PRESERVATION}

The radiolarian material from Leg 58 is generally poorly preserved. Rarely is the preservation better than grade 4 of Westberg and Riedel (1978), and often it is worse. The only material that would be considered of grade 1 or 2 is that from the first intervals of Sites 442 , 443 , and 444 . The two intervals at Site 446 which contained radiolarians are of grade 2 or 3.

Figure 2 shows preservation of radiolarians for intervals from which identifiable radiolarians were recovered. Other than those of the middle to late Miocene and late Pleistocene, the recovered radiolarians are not well preserved.

Stratigraphic ranges of species in material from Leg 58 are most likely not controlled by their presence in the ocean of that time, but by their preservation or nonpreservation after death. Range charts would be misleading and therefore are not included in this report. 
TABLE 1

Radiolarians at Site 442

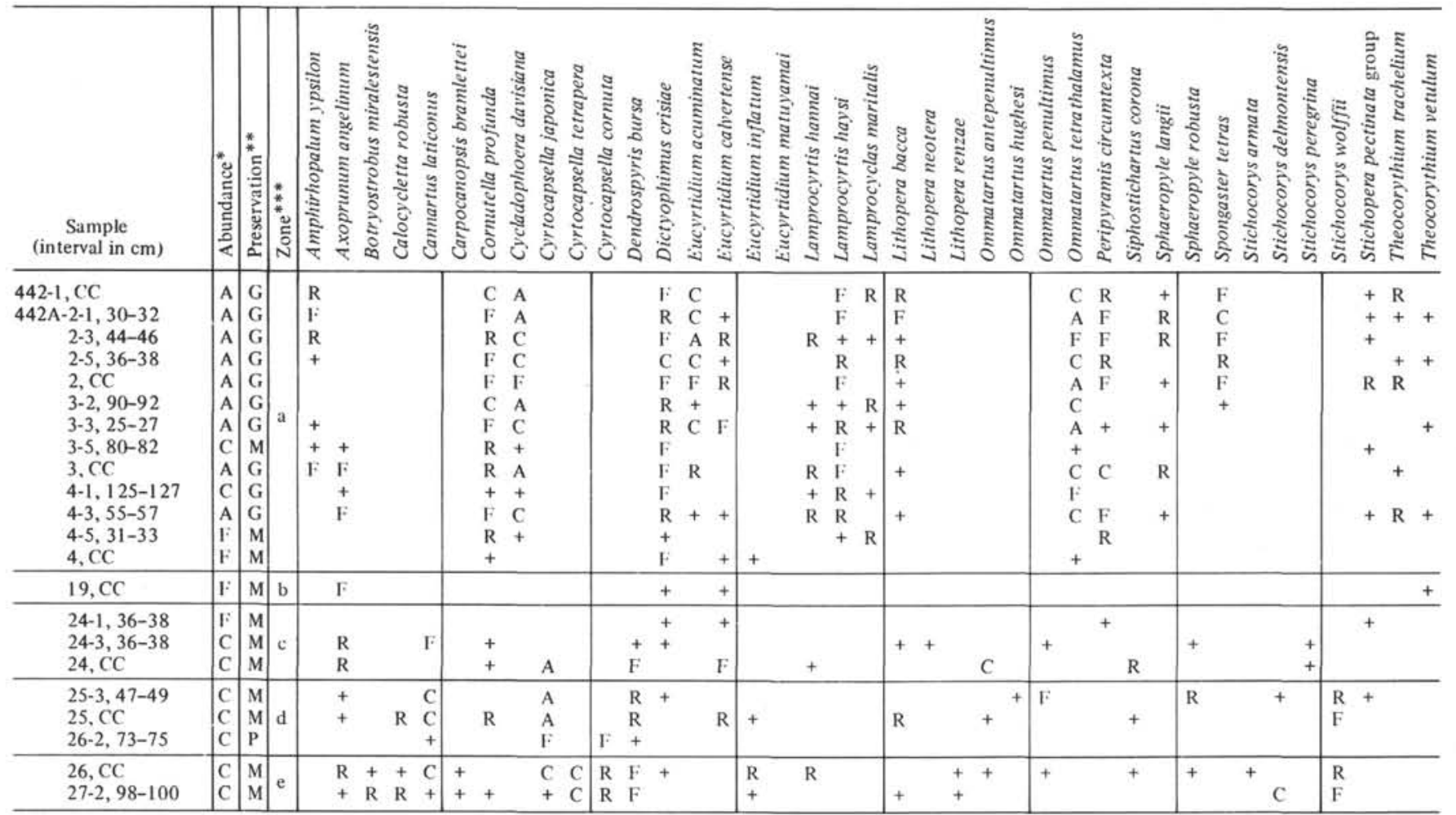

${ }^{*} \mathrm{~A}=$ abundant $(>20) ; \mathrm{C}=$ common $(11-20) ; \mathrm{F}=$ few $(7-10) ; \mathrm{R}=$ rare $(4-6) ;+=$ present $(1-3)$

** $\mathrm{G}=$ good; $\mathrm{M}=$ moderately good: $\mathrm{P}=$ poor.

*** $\mathrm{a}=$ Lamprocyrtis haysi Zone; $\mathrm{b}=$ Spongaster Pentas $\mathrm{Zone} ; \mathrm{c}=$ Ommatartus antepenultimus Zone; $\mathrm{d}=$ Cannartus petterssoni $\mathrm{Zone} ; \mathrm{e}=$ Dorcadospyris alata Zone.

The total production of opal by organisms in the ocean (diatoms, radiolarians, sponges, silicoflagellates, etc.) is $80-160 \times 10^{9}$ tons per year; 4 per cent of this amount reaches the sea floor, and only 50 per cent of that reaching the sea floor is preserved (Lisitzin, 1972). Of the preserved tests, more are lost or altered by diagenetic processes. The recovery of siliceous microfossils from deep-sea sediment depends on multiple interacting factors, including:

1. Productivity. If a large amount of silica is biologically extracted from sea water, more tends to be preserved.

2. Morphology of the species. Robust species are preferentially preserved in sediments.

3. Sedimentation rate. A high sedimentation rate will promote burial of tests and their protection from undersaturated circulating sea water.

4. Deposition in fecal pellets. The organic sheath around most fecal pellets of filter-feeding organisms protects the enclosed tests from dissolution by: (a) Isolation from sea water during settling; (b) Increasing their sinking rate due to a smaller surface-to-volume ratio; (c) Providing a microenvironment of high silica in the surface sediment until burial.

5. Mastication by deposit feeders. Volcanic glass in combination with benthic organisms may fragment radiolarian tests.
6. Chert formation. At a level at which chert is encountered, or just above this level, radiolarian preservation is good to poor, but poor preservation is the rule within cherty sediments. No explanation is known.

Site 446 shows the influences of most of these factors. Sediment accumulation during the deposition of Cores 446-1 through 446-16 was very slow. This very low sedimentation rate may have allowed the tests of radiolarians (and all other microfossils as well) to dissolve before they were covered by sediment. Radiolarian preservation in Core 446-9, which has a very high ash content, is good. Sediments which accumulate slowly have little organic matter and support a small benthic population. Areas of normally low sedimentation rates and high ash fall may allow good radiolarian preservation, as in Core 446-9. An alternative explanation set forth by Riedel (1959a) is that the volcaniclastic material provides dissolved silica to the sediment, saturating the interstitial water and thus preserving the biogenic opal; this explanation is now believed to be in error. Laboratory experiments have shown that volcanic silica is more stable than biogenic silica (Heath, 1974) and would be mobilized more slowly in sediments than the tests of siliceous organisms. In areas of high volcaniclastic sedimentation and large benthic populations (high organic matter), biogenic silica is preserved, but in a fragmented state (seen at Site 443). With a high, 
TABLE 2

Radiolarians at Site 443

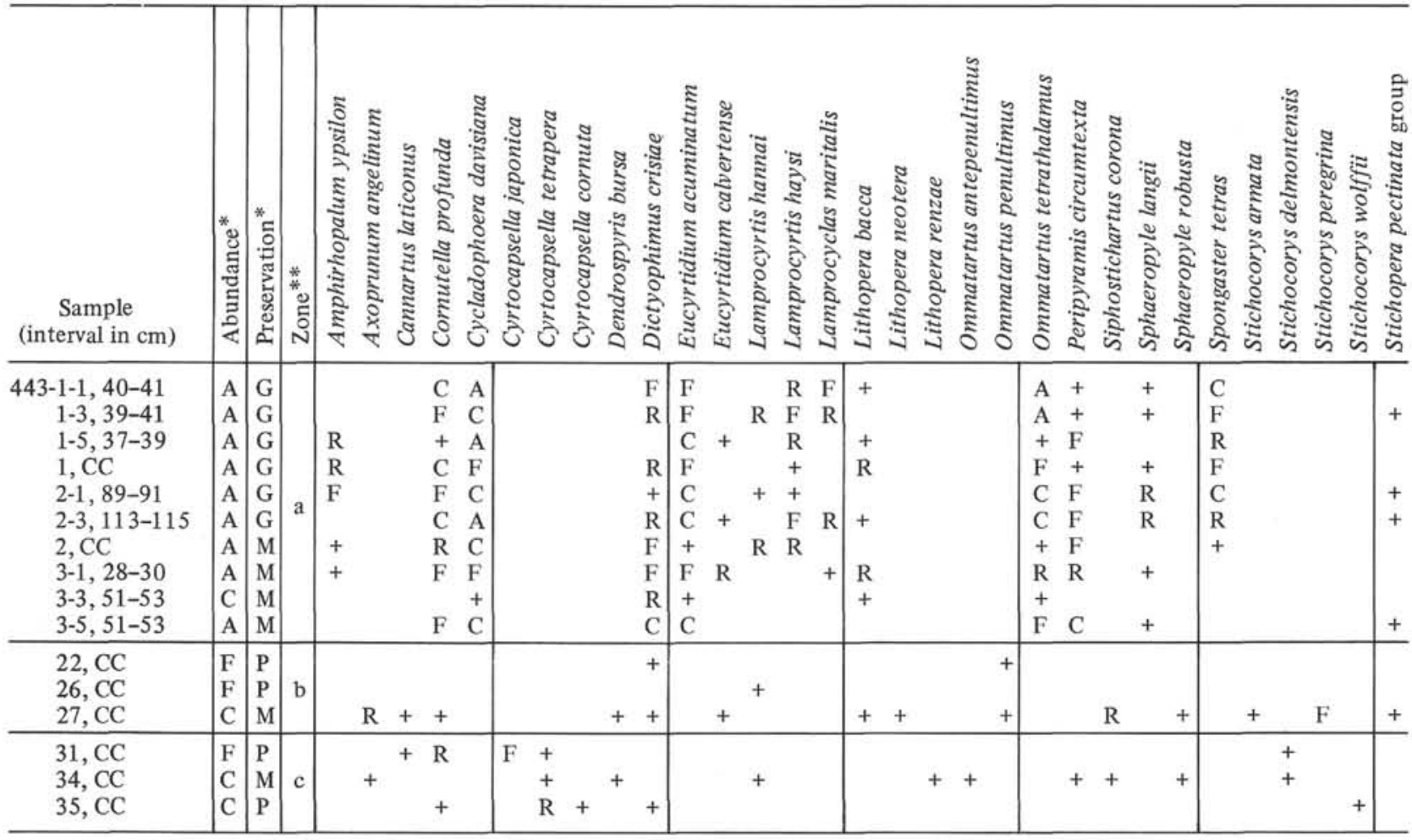

*Symbols as in Table 1.

$*_{\mathrm{a}}=$ Lamprocyrtis haysi Zone $\mathrm{b}=$ Stichocorys peregrina $\mathrm{Zone} ; \mathrm{c}=$ Dorcadospyris alata Zone.

episodic sedimentation rate and little bioturbation, as in the ash layer of Core $446-9$, radiolarian preservation will be best.

The second interval with well-preserved radiolarians at Site 446 (Core 446-17) is believed to be related to the chertification process. Well-preserved radiolarians were noted at Sites $\mathbf{4 4 5}$ and $\mathbf{4 4 6}$ with the first encounter of chert (upper Eocene). The mechanisms of initiation of chert formation are unknown; increased biogenic-silica production; deep burial, with associated temperature increase; and changing interstitial-water chemistry are factors which might influence its formation. From Core 446-17 to the bottom of the hole, radiolarians are common to abundant, but are altered to an advanced degree. This again is associated with the formation of chert. The less-stable, amorphous opal of biogenic organisms is being replaced by or transformed to a more-stable, microcrystalline form of silica (Heath and Moberly, 1971). This is recognized in the loss of resolution of fine structures of the radiolarian tests. Two thin sections of chert were examined, but no radiolarians were found. However, partially replaced foraminifers were seen. Because of the "softness" of a chert pebble in Core 446-18, it is thought to be immature and to contain a large proportion of non-silicate matter. Older chert (Core 446-36) is much harder and is thought to be more mature. This may imply that chert formation is advancing up-section, but this remains uncertain.

During deposition of the Eocene sediments at Site 446 , the area was at a more-tropical latitude (Kinoshita, this volume); it has been influenced by western boundary currents at least since the middle or late Miocene. For these reasons, it is improbable that barrenness of sediments of siliceous microfossils at this site is due to low productivity (central-gyre conditions) in the overlying waters.

\section{PALEOECOLOGY}

Because of the sparse radiolarian record, paleoecological interpretations must be tentative. The three sites drilled in the Shikoku Basin show similar radiolarian preservation and ecology.

The paleoceanography of an area affects both the paleoecology and preservation of a fauna. The Kuroshio Current is clearly the dominant factor in the ecology of the area. Near it, there would be a larger tropical component in the fauna, and where (or when) it is not directly influencing the waters of an area, cold-water species from the north and east would account for a greater proportion of the total fauna. When the Kuroshio meander is not present (Taft, 1972), colder waters from the east move over the area, causing the observed mixed death assemblage. Diatoms also show this same mixed death assemblage; common fragments of the tropical diatom Ethmodiscus rex occur with abundant Coscinodiscus marginatus, a cold-water species (L. Burckle, pers. comm.).

Miocene radiolarians are believed to be of a midlatitude fauna. Because of poor preservation, this may be more apparent than real. Cold-water species tend to 
TABLE 3

Radiolarians at Site 444

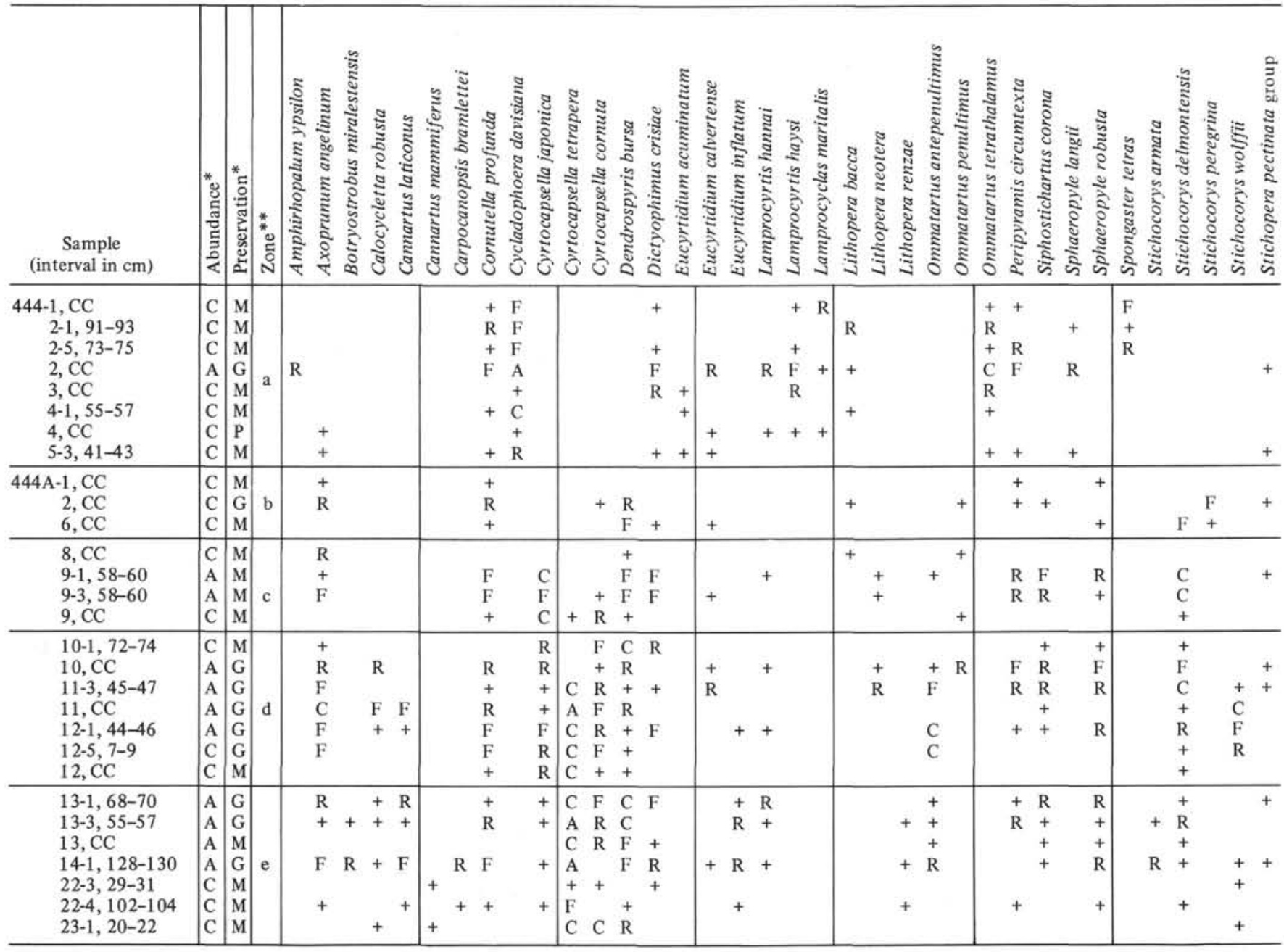

*Symbols as in Table 1.

$* *_{\mathrm{a}}=$ Lamprocyrtis haysi Zone; $\mathrm{b}=$ Stichocorys peregrina $\mathrm{Zone} ; \mathrm{c}=$ Ommatartus antepenultimus Zone; $\mathrm{d}=$ Cannartus petterssoni Zone; $\mathrm{e}=$ Dorcadospyris alata Zone.

be more robust than warm-water species and to resist solution (Petrushevskaya, 1971a,b). Because of selective dissolution of tropical species, the resulting Miocene assemblage appears more non-tropical than it may have been at the time of deposition. Eocene radiolarians (Sites 445 and 446) were rarely found, but are common where preserved. A typical tropical assemblage is found, but without other high-latitude studies of the Eocene this is difficult to interpret. The paleomagnetism data for these two sites (Kinoshita, this volume) also suggest a low-latitude position during the Eocene. It is not known why the Pliocene sediments yielded no radiolarian fossils, but it is thought to be an effect of taphonomy and not ecology.

\section{APPENDIX \\ SPECIES LISTS}

The species listed here first were observed during the investigation of Leg $\mathbf{5 8}$ material. More-complete taxonomic information may be found in earlier DSDP reports. For some species, a reference is given, where a description or figure may be found; where no such separate reference is cited, consult the original description. As in all reports on radiolarians from deep-sea sediments, the following list is only a subset of the total fauna.

A second list names radiolarian species which were searched for and not found. Barren samples are cited in a third list.

Amphirhopalum ypsilon Haeckel, 1887, emend. Nigrini, 1967 (genus). A form in which the forked arm splits before leaving the central disk, leaving three asymmetrical arms, was found consistently in the early part of its range. This may be an ancestral form of this species. See Nigrini (1967).

Axoprunum angelinum (Campbell and Clark) [ =Stylosphaera angelina Campbell and Clark, 1944] See Kling (1973).

Botryostrobus miralestensis (Campbell and Clark) [ = Dictyocephalus miralestensis Campbell and Clark] See Nigrini (1967).

Calocyclas hispida (Ehrenberg) [ =Anthocyrtis hispida Ehrenberg, 1873] See Foreman (1973a).

Calocycletta costata (Riedel) [ = Calocyclas costata Riedel, 1959b] See Moore (1972), Riedel and Sanfilippo (1978).

Calocycletta robusta Moore group [ = Calocycletta robusta Moore, 1971; Calocycletta caepa Moore, 1972] See Moore (1972), Riedel and Sanfilippo (1978).

Calocycletta virginis (Haeckel) [ = Calocyclas virginis Haeckel, 1887] Many specimens of this genus are broken, and the feet are lost. Because of this, the counts of $C$. robusta group and $C$. virginis are 
TABLE 4

Radiolarians at Site 445

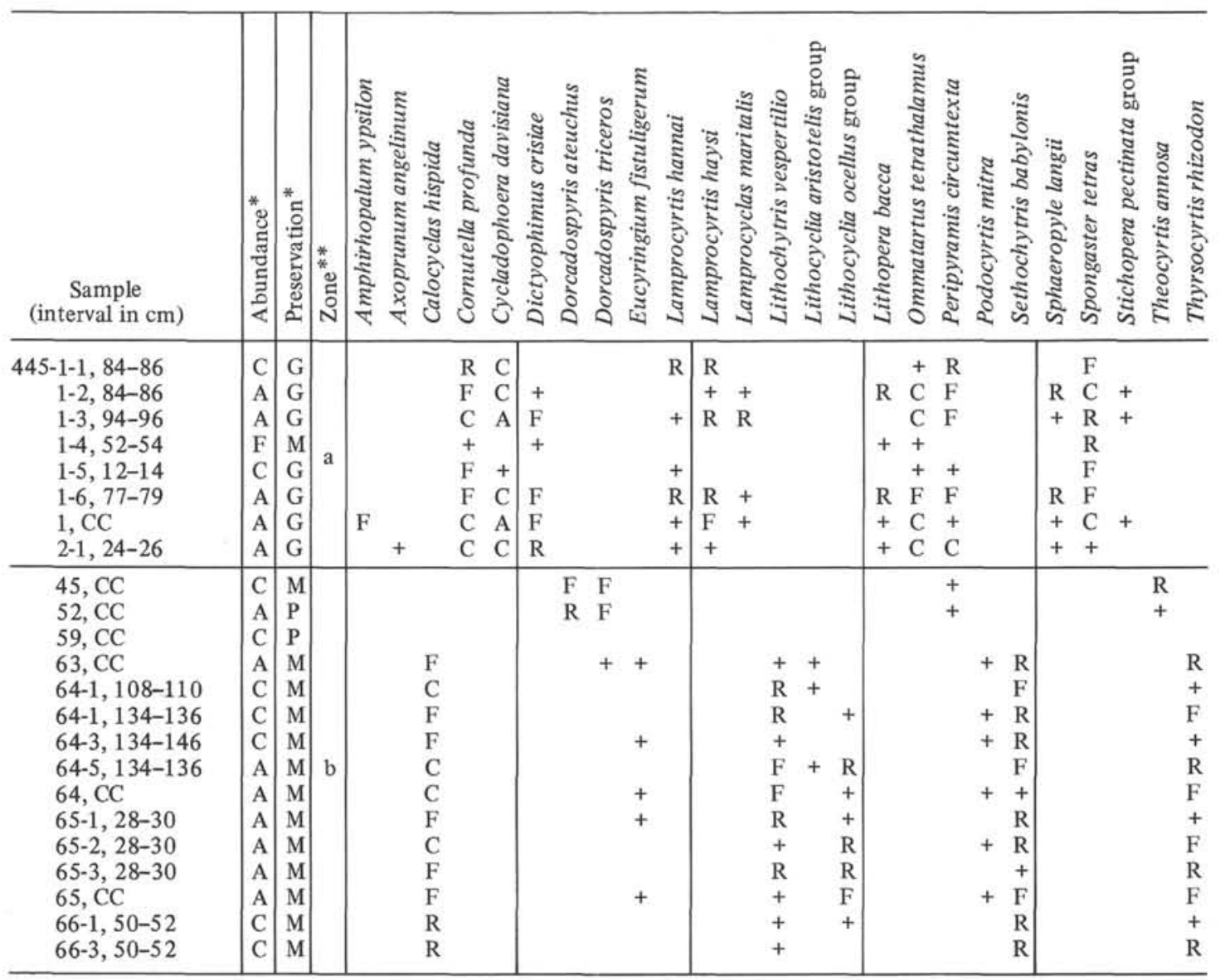

*Symbols as in Table 1 .

${ }^{*} \mathrm{a}=$ Lamprocyrtis haysi Zone $; \mathrm{b}=$ Podocyrtis chalara Zone.

TABLE 5

Radiolarians at Site 446

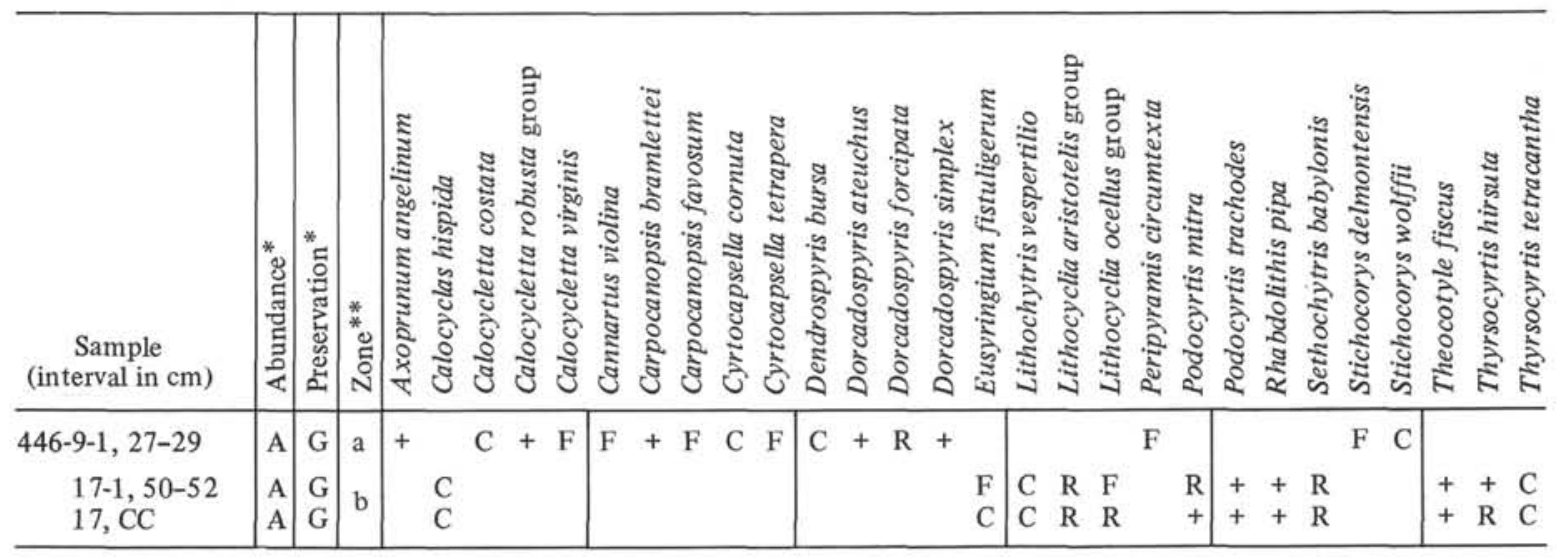

*Symbols as in Table 1.

$* *_{\mathrm{a}}=$ Calocycletta costata Zone; $\mathrm{b}=$ Pococyrtis chalara Zone.

approximate at best. See Moore (1972), Riedel and Sanfilippo (1978).

Cannartus laticonus Riedel, 1959b See Riedel (1959b), Westberg and Riedel (1978).
Cannartus mammiferum (Haeckel) [= Cannartidium mammiferum Haeckel, 1887] This species is very rare in the material from Leg 58. The narrow spongy columns often are thought to have broken off, making this species indistinguishable from Cannartus lati- 


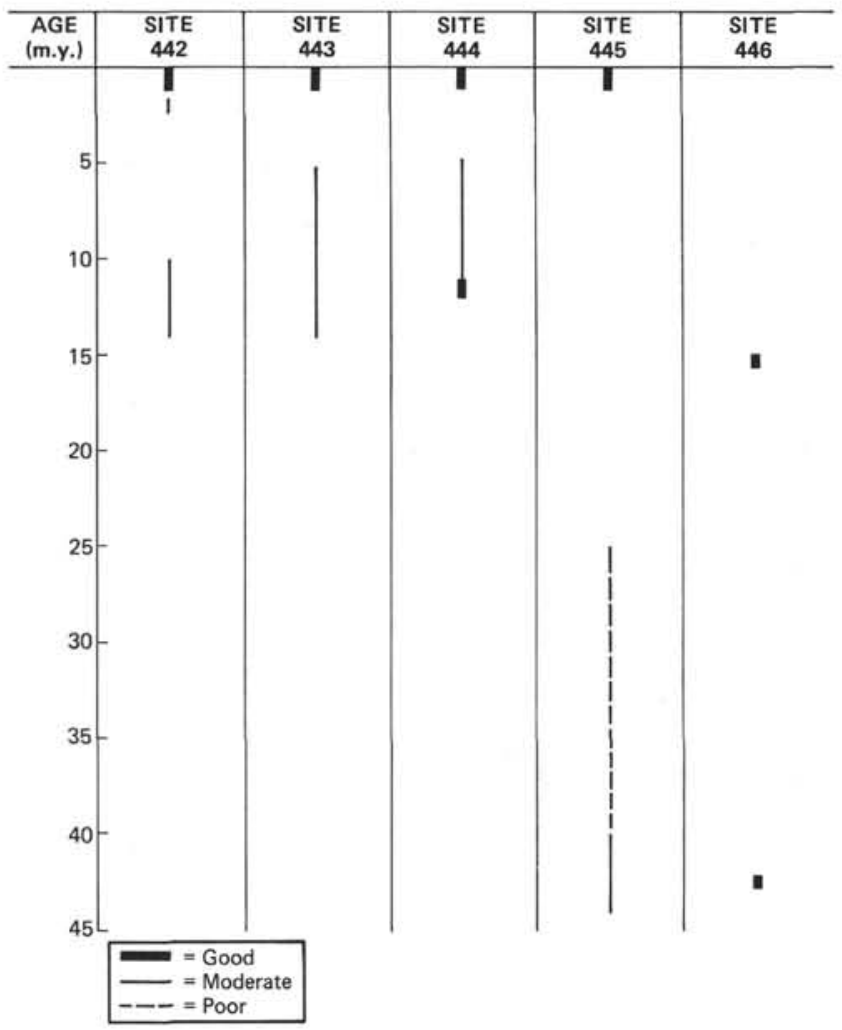

Figure 2. Preservation of radiolarian faunas at each Leg 58 site.

conus. No individuals were counted without some spongy columns or caps. See Riedel (1959b), Ling (1975).

Cannartus violina Haeckel, 1887 See Riedel (1959b).

Carpocanopsis bramlettei Riedel and Sanfilippo, 1971 See Riedel and Sanfilippo (1971).

Carpocanopsis favosum (Haeckel, [ = Cycladophora favosa Haeckel, 1887] See Riedel and Sanfilippo (1971).

Cornutella profunda Ehrenberg [ = Cornutella clathrata ? $\beta$ profunda Ehrenberg, 1854] This variable cold-water species is included here for its ecologic information, although its biostratigraphic importance is minimal. See Riedel (1958), Nigrini (1967).

Cycladophora davisiana Ehrenberg, 1861 This species may also be placed in the genus Theocalyptra (Riedel, 1958). See Ling (1975), Kling (1973).

Cyrtocapsella cornuta Haeckel [ = Cyrtocapsa (Cyrtocapsella) cornuta Haeckel, 1887] See Riedel and Sanfilippo (1971).

Cyrtocapsella japonica (Nakaseko) [ = Eusyringium japonicum Nakaseko, 1963] See Riedel and Sanfilippo (1971).

Cyrtocapsella tetrapera Haeckel. [ = Cyrtocapsa (Cyrtocapsella) tetrapera Haeckel, 1887] See Riedel and Sanfilippo (1971).

Dendrospyris bursa Sanfilippo and Riedel, 1973, in Sanfilippo et al. As in other studies in the Pacific, a horn is lacking from the forms studied in this material. See Sanfilippo et al. (1973), Foreman (1975).

Dictyophimus crisiae Ehrenberg, 1854 See Kling (1973).

Dorcadospyris alata (Riedel) [= Brachiospyris alata Riedel, 1959b] See Riedel (1959b), Moore (1971).

Dorcadospyris ateuchus (Ehrenberg) [ = Ceratospyris ateuchus Ehrenberg, 1873] See Riedel (1959b).

Dorcadospyris forcipata (Haeckel) [ = Dipospyris forcipata Haeckel, 1887] See Riedel (1959b).

Dorcadospyris simplex (Riedel) [=Brachiospyris simplex Riedel, 1959b].

Dorcadospyris triceros (Ehrenberg) [ = Ceratospyris triceros Ehrenberg, 1874] See Riedel (1959b), Moore (1971).
Eucyrtidium acuminatum (Ehrenberg) [ = Lithocampe acuminatum Ehrenberg, 1844] See Nigrini (1967).

Eucyrtidium calvertense Martin, 1904 See Hays (1965), Kling (1973).

Eucyrtidium inflatum Kling, 1973

Eucyrtidium matuyamai Hays, 1970 See Kling (1973).

Eusyringium fistuligerum (Ehrenberg) [ =Eucyrtidium fistuligerum Ehrenberg, 1873] See Riedel and Sanfilippo (1970).

Lamprocyclas maritalis Haeckel, 1887 The form seen here is $L$. maritalis maritalis of Nigrini (1967). L. m. polypora of Nigrini (1967) was searched for and not found. See Nigrini (1967).

Lamprocyrtis hannai (Campbell and Clark) [=Calocyclas hannai Campbell and Clark, 1944] See Kling (1973).

Lamprocyrtis haysi Kling, 1973

Lithochytris vespertilio Ehrenberg, 1873 See Riedel and Sanfilippo (1970).

Lithocyclia aristoltelis (Ehrenberg) group [ =Astromma aristoltelis Ehrenberg, 1847] See Riedel and Sanfilippo (1970).

Lithocyclia ocellus Ehrenberg, 1854 group See Riedel and Sanfilippo (1970)

Lithopera bacca Ehrenberg, 1872 See Nigrini (1967).

Lithopera neotera Sanfilippo and Riedel, 1970

Lithopera renzae Sanfilippo and Riedel, 1970

Ommatartus antepenultimus Riedel and Sanfilippo, 1970 See Riedel and Sanfilippo (1970), Ling (1975).

Ommatartus hughsi (Campbell and Clark) [ = Ommatocampe hughesi Campbell and Clark, 1944] See Riedel and Sanfilippo (1978).

Ommatartus penultimus (Riedel) $[=$ Panarium penultimum Riedel, 1957]. See Westberg and Reidel (1978).

Ommatartus tetrathalamus (Haeckel) [= Panartus tetrathalamus Haeckel, 1887] See Nigrini (1967).

Peripyramis circumtexta Haeckel, 1887 See Campbell and Clark (1944); Riedel (1958).

Podocyrtis mitra Ehrenberg, 1854 See Riedel and Sanfilippo (1970).

Podocyrtis trachodes Riedel and Sanfilippo, 1970

Rhabdolithis pipa Ehrenberg, 1854 See Sanfilippo and Riedel (1973).

Sethochytris babylonis (Clark and Campbell) group [ = Dictyophimus babylonis Clark and Campbell, 1942] See Riedel and Sanfilippo (1970).

Siphostichartus corona (Haeckel) [ = Cyrtophormis corona Haeckel, 1887] See Nigrini (1977).

Sphaeropyle langii Dreyer, 1889 See Foreman (1975).

Sphaeropyle robusta Kling 1973 See Kling (1973), Foreman (1975).

Spongaster tetras Ehrenberg, 1860 Both subspecies $S$. $t$. tetras and $S$. $t$. irregularis were seen. Their relative abundances were compiled for an ecological study. See Nigrini (1967), Riedel and Sanfilippo (1978).

Stichocorys armata (Haeckel) [=Cyrtophormis armata Haeckel, 1887] See Sanfilippo et al. (1973).

Stichocorys delmontensis (Campbell and Clark) [=Eucyrtiduum delmontense Campbell and Clark, 1944] The criterion of Westberg and Riedel (1978) which aids in distinguishing this species from the following is appreciated and utilized. See Westberg and Riedel (1978).

Stichocorys peregrina (Riedel) [ = Eucyrtidium elongatum pergrinum Riedel, 1953] See Westberg and Riedel (1978).

Stichocorys wolffii Haeckel, 1887 See Riedel (1957), Riedel and Sanfilippo (1978).

Stichopera pectinata Haeckel, 1887 group This group is added for ecologic information. See Casey $(1971,1977 ;=$ Cyrtopera laguncula Haeckel). See Kling (1973).

Theocorythium trachelium trachelium (Ehrenberg) [ = Eucyrtidium trachelium Ehrenberg, 1872] $T$. $t$. dianae was searched for and not found. See Nigrini (1967).

Theocorythium vetulum Nigrini, 1971

Theocotyle ficus (Ehrenberg) [ = Eucyritidium ficus Ehrenberg, 1873] See Riedel and Sanfilippo (1970).

Theocyrtis annosa (Riedel) [ = Phormocyrtis annosa Riedel, 1959b] See Riedel and Sanfilippo (1978).

Thyrsocyrtis hirsuta (Krasheninnikov) [=Podocyrtis hirsutus Krasheninnikov, 1960] See Foreman (1973a).

Thyrsocyrtis rhizodon Ehrenberg, 1873 See Riedel and Sanfilippo (1970), Foreman (1973a). 
Thyrsocyrtis tetracantha (Ehrenberg) [= Podocyrtis tetracantha Ehrenberg, 1873] See Riedel and Sanfilippo (1978).

The following species were searched for and not found:

Arthophormis gracilis Riedel

Cannartus petterssoni Riedel and Sanfilippo

C. prismaticus (Haeckel)

C. tubarius (Haeckel)

Cyclampterium brachythorax Sanfilippo and Riedel

C. milowi Riedel and Sanfilippo

Cyrtocapsella elongata (Hakaseko)

Dorcadospyris dentata Haeckel

D. pipilio (Riedel)

D. praeforcipata Moore

Lamprocyclas maritalis polypora Haeckel

L. heteroporos (Hays)

L. neoheteroporos Kling

Lithocyclia angusta (Riedel)

Lithopera baueri Sanfilippo and Riedel

$L$. thornburgi Sanfilippo and Riedel

Lychnocanoma elongata (Vinassa)

L. trifolium (Riedel and Sanfilippo)

Phormostichoartus corbula (Harting)

Pterocanium prismatium Riedel

Spongaster pentas Riedel and Sanfilippo

Stichocorys diploconus (Haeckel)

Theocorys spongoconus Kling

Theocorythium trachelium dianae (Haeckel)

Theocyrtis tuberosa Riedel

Triactis tripyramis Haeckel

The following 278 samples were examined, but contain too few or poorly preserved radiolarians for reliable biostratigraphic or paleoecologic information.

\begin{tabular}{|c|c|c|}
\hline $442 \mathrm{~A}-4, \mathrm{CC}$ & $2-1,11-13$ & $10-2,122-124$ \\
\hline $5-1,75-77$ & $2-3,42-44$ & $10, \mathrm{CC}$ \\
\hline $5-3,95-97$ & $2, \mathrm{CC}$ & \\
\hline $5-5,56-58$ & $3-2,130-132$ & $444 \mathrm{~A}-1-1,135-137$ \\
\hline $5, \mathrm{CC}$ & $9, \mathrm{CC}$ & $1-3,86-88$ \\
\hline $6-1,108-110$ & & $2-2,124-126$ \\
\hline $6-3,66-68$ & $443-3, C C$ to $21, C C$ & $3-3,99-101$ \\
\hline $6-5,72-74$ & $23, \mathrm{CC}$ & $3-5,99-101$ \\
\hline $6, \mathrm{CC}$ to $18, \mathrm{CC}$ & $24, \mathrm{CC}$ & $3, \mathrm{CC}$ \\
\hline $19-1,104-106$ & $28, \mathrm{CC}$ & $6-1,24-26$ \\
\hline $19-3,25-27$ & $29, \mathrm{CC}$ & $6-3,24-26$ \\
\hline $20-1,114-116$ & $32, \mathrm{CC}$ & $7, \mathrm{CC}$ \\
\hline $20, \mathrm{CC}$ & $33, \mathrm{CC}$ & $11-1,142-144$ \\
\hline $21-1,100-102$ & $36, \mathrm{CC}$ to $40, \mathrm{CC}$ & $14-3,53-55$ \\
\hline $21-3,72-74$ & $42, \mathrm{CC}$ to $48, \mathrm{CC}$ & $14, \mathrm{CC}$ \\
\hline $21, \mathrm{CC}$ & & $15-1,81-83$ \\
\hline $22-1.87-89$ & $444-2-3,81-83$ & $15-3,53-55$ \\
\hline $22, \mathrm{CC}$ & $3-1,30-32$ & $15, \mathrm{CC}$ \\
\hline $23-1,37-39$ & $3-3,5-7$ & $16-1,50-52$ \\
\hline $23-3,37-39$ & $4-3,52-54$ & $21-1,87-89$ \\
\hline $23, \mathrm{CC}$ & $4-5,7-9$ & $21, \mathrm{CC}$ \\
\hline $28-1,78-80$ & $5-1,33-35$ & $22-1,16-18$ \\
\hline $28-3,78-80$ & $5, \mathrm{CC}$ & $22, \mathrm{CC}$ \\
\hline $28, \mathrm{CC}$ & $6-1,39-41$ & $23-1,20-22$ \\
\hline $29-1,29-31$ & $6, \mathrm{CC}$ & \\
\hline $29-3,97-99$ & $7-2,43-45$ & $445-2, \mathrm{CC}$ to $7, \mathrm{CC}$ \\
\hline $29, \mathrm{CC}$ & $73-3,104-106$ & $9, \mathrm{CC}$ to $45, \mathrm{CC}$ \\
\hline $30-1,28-30$ & $7-6,39-41$ & $46, \mathrm{CC}$ to $51, \mathrm{CC}$ \\
\hline $30, \mathrm{CC}$ & $7, \mathrm{CC}$ & $54, \mathrm{CC}$ \\
\hline \multirow[t]{2}{*}{$31-1,29-30$} & $8-1,60-62$ & $55, \mathrm{CC}$ \\
\hline & $8, \mathrm{CC}$ & $57, \mathrm{CC}$ \\
\hline 442B-1-1, 137-139 & $9-1,87-89$ & $60, \mathrm{CC}$ to $62, \mathrm{CC}$ \\
\hline $1-3,29-31$ & $9, \mathrm{CC}$ & $67-1,39-41$ \\
\hline $1, \mathrm{CC}$ & $10-1,88-90$ & $67, \mathrm{CC}$ \\
\hline
\end{tabular}

\begin{tabular}{lll}
\hline $68-1,23-25$ & $39-2,45-47$ & $10-1,108-110$ \\
$69-1,36-38$ & $39, C C$ & $10-3,0-2$ \\
$69-3,36-38$ & $40-1,43-47$ & $10-5,38-40$ \\
$71, C C$ to $86, C C$ & $41-1,117-119$ & $12-3,77-78$ \\
& $41-3,46-48$ & $13-3,142-143$ \\
$446-1-1,98-100$ & $43-1,52-53$ & $13, C C$ \\
$1, C C$ to $8, C C$ & $43-2,129-130$ & $14-1,12-13$ \\
$9, C C$ to $16, C C$ & $43-3,142-143$ & $16-4,144-146$ \\
$18, C C$ & & $16-5,10-12$ \\
$19, C C$ & & $17-1,140-142$ \\
$20-1,29-30$ & & $17, C C$ \\
$20, C C$ to $35, C C$ & $446 \mathrm{~A}-1-2,31-33$ & $18-1,116-118$ \\
$36-5,35-37$ & $1-3,31-33$ & $18-2,38-40$ \\
$36, C C$ & $1, C C$ & $22-1,61-62$ \\
$38-1,67-69$ & $2, C C$ & $23-1,60-62$ \\
$38-3,35-37$ & $3-1,100-102$ & $24-1,91-93$ \\
$38-5,51-53$ & $3-2,140-142$ & $24-2,71-72$ \\
$38-6,52-54$ & $3-3,14-16$ & $25, C C$ \\
\hline
\end{tabular}

\section{REFERENCES}

Campbell, A. S., and Clark, B. L., 1944. Miocene radiolarian faunas from Southern California. Geol. Soc. Am. Spec. Paper, 51.

Casey, R. E., 1971. Radiolarians as indicators of past and present water masses. In Funnell, B. M., and Riedel, W. R. (Eds.), The Micropaleontology of Oceans: Cambridge (Cambridge University Press), pp. 331-341. 1977. The ecology and distribution of Recent Radiolaria. In Ramsay, A. T. S. (Ed.), Oceanic Micropalaeontology (Vol. 2): pp. 809-845.

Clark, B. L., and Campbell, A. S., 1942. Eocene radiolarian faunas from the Mt. Diablo area, California. Geol. Soc. Am. Spec. Paper, 39.

Dreyer, F., 1889. Morphologische Radiolarienstudien. 1. Die Pylombildungen in vergleichend-anatomischer und entwicklungsgeschichtlicher Beziehung bei Radiolarien und bei Protisten uberhaupt, nebst System und Beschreibung neuer und der bis jetzt bekannten pylomatischen Spumellarien. Jena. Zeitschr. Naturw., 23, new ser., 16, 1-138.

Ehrenberg, C. G., 1844. Uber 2 neue Lager von Gebirgsmassen aus Infusorien als Meeres-Absatz in Nord-Amerika und eine Vergleichung derselben mit den organischen KreideGebilden in Europa und Afrika. Kgl. Preuss. Akad. Wiss. Berlin, Ber. Jahre 1844, 57-97. 1847. Uber eine halibiolithische, von Herrn R. Schomburgk entdeckte, vorherrschend aus mikroskopischen Polycystinen gebildete, Gebirgsmasse von Barbados. Kgl. Preuss. Akad. Wiss. Berlin, Ber. Jahre 1846, 382-385. 1854. Mikrogeologie: Leipzig (Voss).

1860. Uber den Tiefgrund des stillen Oceans zweischen Californien und den Sandwich-Inseln aus bis $15600^{\prime}$ tiefe nach Lieut. Brooke. Kgl. Preuss. Akad. Wiss. Berlin, Monatsber. Jahre 1860, 819-833.

, 1861. Uber die Tiefgrund-Verhaltnisse des Oceans am Eingange der Davisstrasse und bei Island. Kgl. Preuss. Akad. Wiss. Berlin, Monatsber. Jahre 1861, 275-315. 1872. Mikrogeologischen Studien als Zusammenfassung der Beobachtungen des kleinsten Lebens der Meeres Tiefgrunde aller Zonen und dessen geologischen Einfluss. Kgl. Preuss. Akad. Wiss. Berlin, Monatsber. Jahre 1872, 265-322.

1873-1874. Grossere Felsproben des PolycystinenMergels von Barbados mit weiteren Erlauterungen. $\mathrm{Kgl}$. Preuss. Akad. Wiss. Berlin, Ber. Jahre 1873, 213-263.

Foreman, H. P.,1973. Radiolaria of leg 10 with systematics and ranges for the families Amphipyndacidae, Artostrobiidae, and Theoperidae. In Worzel, J. L., Bryant, 
W., et al., Init. Repts. DSDP, 10: Washington (U. S. Govt. Printing Office), pp. 407-474.

, 1975. Radiolaria from the North Pacific, Deep Sea

Drilling Project Leg 32. In Larson, R. L., Moberly, R., et al., Init. Repts. DSDP, 32: Washington (U. S. Govt. Printing Office), pp. 579-676.

Haeckel, E. 1887. Report on the Radiolaria collected by H.M.S. Challenger during the years 1874-76. Rept. Voyage Challenger, Zool., 18.

Hays, J. D. 1965. Radiolaria and late Tertiary and Quaternary history of Antarctic Seas. Biology of Antarctic Seas 11, Antarctic Research Ser., 5, 124-184. 1970. Stratigraphy and evolutionary trends of Radiolaria in North Pacific deep sea sediments. In Hays, J. D. (Ed.), Geological Investigations of the North Pacific: Geol. Soc. Am. Mem., 126.

Heath, G. R., 1974. Dissolved silica and deep-sea sediments. In Hay, W. W., Studies in Paleo-oceanography. SEPM Spec. Pub., No. 20.

Heath, G. R., and Moberly, R., 1971. Cherts from the Western Pacific, Leg 7, Deep Sea Drilling Project. In Winterer, E. L., et al.., Init. Repts. DSDP, 7: Washington (U. S. Govt. Printing Office), pp. 991-1007.

Kling, S. A. 1973. Radiolaria from the Eastern North Pacific, Deep Sea Drilling Project, Leg 18. In Kulm, L. D., von Huene, R., et al., Init. Repts. DSDP, 18: Washington (U. S. Govt. Printing Office) pp. 617-67.

Krasheninnikov, V. A., 1960. Nekotorye radiolyarii nizhnego i srednego eotsena zapadnogo predkavkazya. Min. Geol. $i$ Okhr. Nedr SSSR Vses. Nauch. Issled., Geol. Neft. Inst., 16, 271-301.

Ling, H. Y., 1975. Radiolaria: Leg 31 of the Deep Sea Drilling Project. In Karig, D. E., Ingle, J. C., Jr., et al., Init. Repts. DSDP, 31: Washington (U. S. Govt. Printing Office), pp. 703-761.

Lisitzin, A. P., 1972. Sedimentation in the World Ocean. SEPM Spec. Pub., No. 17.

Martin, G. C., 1904. Radiolaria (Miocene): Maryland Geol. Survey.

Moore, T. C., Jr., 1971. Radiolaria. In Tracey, J. I., Jr., Sutton, G. H., et al., Init. Repts. DSDP, 8: Washington (U. S. Govt. Printing Office), pp. 727-776.

, 1972. Mid-Tertiary evolution of the radiolarian genus Calocycletta. Micropaleont., 18(2), 144-152.

Nakaseko, K., 1963. Neogene Cyrtoidea (Radiolaria) from the Isozaki Formation in Ibaraki Prefecture Japan. Sci. Rept. Osaka Univ., 12, 165-198.

Nigrini, C., 1967. Radiolaria in Pelagic Sediments from the Indian and Atlantic Oceans. Bull. Scripps Inst. Oceanog. Univ. Calif., 11.
1971. Radiolarian zones in the Quaternary of the Equatorial Pacific Oean. In Funnell, B. M., and Riedel, W. R. (Eds.), The Micropaleontology of Oceans: Cambridge (Cambridge University Press), pp. 443-461.

1977. Tropical Cenozoic Artostrobiidae (Radiolaria). Micropaleont., 23(3), 241-269.

Petrushevskaya, M. G., 1971. Spumellarian and nassellarian Radiolaria in the plankton and bottom sediments of the Central Pacific. In Funnell, B. M., and Riedel, W. R. (Eds.), The Micropaleontology of Oceans: Cambridge (Cambridge University Press), pp. 309-317.

Riedel, W. R., 1953. Mesozoic and late Tertiary Radiolaria of Rotti. J. Paleont., 27, 805-813.

1957. Radiolaria: a preliminary stratigraphy. Rept. Swed. Deep-Sea Exped., 6(3), 59-96.

1958. Radiolaria in Antarctic sediments. Rept. B.A.N.Z. Antarct. Res. Exped., ser. B., 6, pt. 10, 217-255. 1959a. Siliceous organic remains in pelagic sediments. In Silica in Sediments. S.E.P.M. Spec. Publ., 7, 80-91.

, 1959b. Oligocene and lower Miocene Radiolaria in tropical Pacific sediments. Micropaleont., 5(3), 285-302.

Riedel, W. R., and Sanfilippo, A., 1970. Radiolaria, Leg 4, Deep Sea Drilling Project. In Bader, R. G., Gerard, R. D., et al., Init. Repts. DSDP, 4: Washington (U. S. Govt. Printing Office), pp. 503-575.

1971. Cenozoic Radiolaria from the western tropical Pacific, Leg 7. In Winterer, E. L., Riedel, W. R., et al., Init. Repts. DSDP, 7: Washington (U. S. Govt. Printing Office), pp. 1529-1672.

1973. Cenozoic Radiolaria from the Caribbean, DSDP Leg 15. In Edgar, N. T., Saunders, J. B., et al., Init. Repts. DSDP, 15: Washington (U. S. Govt. Printing Office), pp. 705-751.

1978. Stratigraphy and evolution of tropical Cenozoic radiolarians. Micropaleont., 24(1), 61-96.

Sanfilippo, A., Burckel, L. H., Martini, E., and Riedel, W. R., 1973. Radiolarians, diatoms, silicoflagellates and calcareous nannofossils in the Mediterranean Neogene. Micropaleont., 19(2), 209-234.

Sanfilippo, A., and Riedel, W. R., 1970. Post-Eocene "closed" theoperid radiolarians. Micropaleont., 16(4), 446-462.

Taft, B. A., 1972. Characteristics of the flow of the Kuroshio south of Japan. In Stommel, H., and Yoshida, K., (Eds.), Kuroshio - Its Physical Aspects: Tokyo (Univ. of Tokyo Press), pp. 165-216.

Westberg, M. J., and Riedel, W. R., 1978. Accuracy of radiolarian correlations in the Pacific Miocene. Micropaleont., 24(1), 1-23. 